\title{
COMMENTARY
}

\section{Extending Ethnocracy: Reflections and Suggestions}

\author{
Oren Yiftachel \\ Ben-Gurion University of the Negev
}

\begin{abstract}
As prelude to the special issue, this short piece reflects on the scholarly origins of the 'ethnocracy' concept, and comments on the arguments made by James Anderson's insightful opening article. It then outlines several concepts developed in the author's own work in later years as 'offsprings' of ethnocracy. Finally, it answers the challenge raised by Anderson by suggesting future theoretical, conceptual and empirical directions for research into ethnocratic dynamics on urban, state and global scales.
\end{abstract}

This special journal issue, devoted to the concept of 'ethnocracy', is an excellent opportunity to reflect on the making and life of the concept some two decades after its emergence in the social sciences and humanities. It is also an opportunity to evaluate the concept's strengths and weaknesses, and assess its ability to shed light on the nature of political regimes and identity politics during a critical transitional period in the world's political geography. In this short piece I will first reflect on the origins of ethnocratic theory, then briefly comment on Anderson's insightful lead article, and highlight several concepts and research agendas that rest on the foundations of the ethnocratic angle.

To refresh the readers' mind, the term 'ethnocracy' was developed into a comprehensive theory during the 1990s and early 2000s (Yiftachel, 1997, 1999, 2006). It identified a particular regime type, which uses a 'thin' layer of (often distorted) democratic practices, but structurally facilitates - explicitly or implicitly - mechanisms of ethnic control and expansion over contested lands. Ethnocratic theory analysed critically the causes, content, consequences and different trajectories of ethnocratic regimes. It was developed (after years of being 
sporadically mentioned in the literature) following criticism of conventional, typically noncritical scholarship describing the nature of political regimes, (e.g. Alvarez et al. 1996). It was also propelled by a critique of several key concepts that emerged in the 1990s, such as 'nationalizing states' (Brubaker 1996) or 'ethnic democracy' (Smooha 1990, Yiftachel 1992). These discussions exposed a serious void in existing typologies of political regimes, which consistently overlooked the persistence and often neo-colonial nature of ethnic domination in a wide range of states, even during their so-called 'democratic transition'.

While the development of ethnocratic theory was strongly influenced by studying the ZionistPalestinian conflict, the concept was developed by using comparative methods, and hence became equally relevant to other regimes facilitating the domination of a particular identity group over others, such as Malaysia, Sri Lanka, Northern Ireland, Cyprus, Estonia and Serbia. The insightful articles of this special issue, dealing with Fiji, Australia, Lebanon, Ireland, the Baltic States, Sri Lanka and the city of Jerusalem, vividly illustrate this international relevance.

During the 1990s and 2000s, empirical and comparative work on ethnocratic societies resulted in the development of a set of related concepts, seeking to fine-tune the understanding of the logic, workings and consequences of ethnocratic systems of power. These have focused on the impact of spatial, legal and discursive practices on social and political relations, and included concepts such as 'settling ethnocracy', 'ethnicization', 'ethnic religion', 'ethno-class', 'fractured regions', 'trapped minorities', 'stratified citizenship' and 'urban ethnocracy' (See, among others: Anderson 2013; Murtagh and Keaveney 2006; Nagle 2009; Howard 2012; O'Dowd and Komarova 2011; Renemyi 2011; Tuathail, 2013Yiftachel 1997, 1999, 2006; Yiftachel and Yacobi 2000; Yiftachel and Ghanem 2004).

\section{Extending Ethnocracy}

In his perceptive leading article, James Anderson suggests extension of the concept in three related directions, dealing with 'imperial ethnocracy', 'religious-political ethnocracy' and 'post-conflict' ethnocracy. Indeed, such insightful suggestions take the concept into areas of investigation often overlooked in previous work. Conceptually and politically, religion is obviously a major mobilizer of identity and politics. The two decades since the development of 'ethnocracy' have seen a significant rise of religious discourses as key platforms of identity 
conflicts, notably in the Middle East, where political Islam has radically reshaped previous political landscapes and forms of violent conflicts in key states such as Turkey, Egypt, Iraq and Syria. In Israel/Palestine religion has never been far from the political surface, but in recent years its impact has amplified, often positing a radicalizing challenge to state ethnocratic logic (see also Yiftachel and Roded 2010). Likewise, countless political struggles in Africa, Asia, and the Americas and even in Europe have revolved around explicit or implicit notions of religion.

Beyond its empirical validity, the rise of political religion also presents a challenge to the ethnocratic model in ways unpredicted by the original model. New religious politics often promote different sets of political boundaries and horizons around which power is mobilized and contested. In ethnocratic settings, religious identities often overlap ethno-national definitions to create 'ethnic religions', leading to a mutual reinforcement of the two sets of political mobilizations (evident in cases such as Lebanon, The Balkans, Sudan or Northern Ireland). Other times, however, religious boundaries and goals contest state authority and power, particularly when fuelling expansionist agendas, as in some versions of political Judaism and Islam (see Yiftachel and Roded 2010). The unstable relations between ethnonational and religious projects, as Anderson points out well, add an important dimension of ethnic politics yet to be fully analysed or understood.

Anderson's additional idea of extending ethnocracy, 'back' to imperial history, and 'forward' to post-conflict settings, is also highly commendable. Beyond the obvious interest in the historically changing nature of territoriality and identity, it also introduces the importance of time and temporality as critical analytical categories, often underplayed in the study of political geographies and conflicts (see also Jamal 2016; Yiftachel 2016). In ethnocratic societies, the management of time has become a tool for preserving the position of dominant groups, through the portrayal of their history, archaeology and belonging to contested territory as timeless and natural.

In parallel, ethnocratic time management tends to define the existence of other groups as temporary, transient, invasive or uncertain, hence weakening their claims for recognition, belonging and resources. In many ethnocratic states, territorial time has been colonized by the dominant power, with the effect of triggering resistance, hardening identities and deepening conflicts. On the contrary, in federal, multi-cultural or liberal societies, the recognition of 
multiple collective times and overlapping histories have been instrumental in the transition from conflict to coexistence. Therefore, even beyond imperial and post-conflict settings, Anderson's intervention opens up wide horizons for new research on these timely topics.

\section{Further Horizons}

In the spirit of Anderson's discussion, let me now identify other aspects of ethnocratic theory, which call for further scholarly and political attention. These include (but naturally, not limited to) race, gender, immigration and urban regimes. Race is closely related to ethnicity, being a 'biological-like' social and political category constantly changing over time. Racial categories have been commonly imposed over marginalized groups in order to maintain social and political supremacy. The similarities and differences between race and ethnicity in the making of political and spatial power need to be further explored, if we are to fully understand the making and maintenance of ethnocracies and group conflict (see Winant 2011). This is particularly the case in the current age of increasing immigration and refugee movement, as collective identities are increasingly essentialized. At the same time, liberalization and democratization see indigenous and national minorities reassert their demands, thus further fuelling group boundaries and tensions.

Gender, like race, is understudied in the ethnocratic context (for exceptions, see Mostov 1999; Fenster 2005; Yuval-Davis and Werbner 1999). Gender is obviously critical to the very making of ethnic categories and the manner in which they are reproduced. Gender relations are mobilized both to sharpen the differences between collectivities, but also to shape the nature of gender and sexualities within groups. In particular, ethnic conflict and neo-colonial relations often suppress the struggle over gender issues such as abuse, domination, equality, family structure and sexuality, commonly in the name of serving 'higher' collective goals. The typical ethnocratic silencing of gender issues thus facilitates the essentialization of collective identities and the inability of women to challenge their oppression (see: Mostov 1999). But other examples also exist, where women mobilize the struggle to move 'upwards' in the social order, as occurred in the first Palestinian Intifada or with women mobilization in Liberia. Research is these areas can add crucial insights to the understanding of the making and maintenance of oppressive ethnocratic systems, and the manner in which 'cracks' in the system have been exploited to challenge patriarchal ethnocracies. 
Two additional areas of research appear to be vital for the understanding of contemporary ethnocratic societies: immigration and urban regimes. The expansion of the ethnocratic inquiry into these areas has already begun (see: Porter and Barry 2015; Roy 2009). Using a 'grounded theorization' approach, my own work has explored the changing spatio-political positioning of these groups in rapidly expanding urban regions. While these topics still require much more research, it is clear that ethnocratic and racial logics are critical for the understanding of governance and social relations in today's metropolis. This factor has been underplayed in most critical urban and planning theories with the effect of ignoring and/or misunderstanding major political upheavals (Yiftachel 2016). Systematic engagement with urban identity regimes has spawned the development of new concepts, such as 'gray spacin’, ‘dynamic structuralism', ‘creeping apartheid’ and ‘metrozenship’ (Yiftachel 2015). Space limitation prevents proper discussion of these concepts, which can be likened to branches splitting from the core of ethnocratic theories, and shedding light on related, yet different, configurations of power, space and identity.

Immigration, either international or internal, was also previously underplayed in the study of ethnocratic regimes. It has nonetheless become a critical factor in understanding new formations of class and identity, and hence political regimes. The amplifying mobility (of both immigrants and refugees) has been unprecedented in recent years, causing shockwaves to political systems worldwide. The recent examples of Brexit and the rise of Donald Trump in the US are clear illustrations that even in the most liberal capitalist societies, ethnocratic considerations are firmly on the agenda. Hence, the current stage of globalizing capitalism, often portrayed in the literature as either (neo)liberal or color-blind, is strongly implicated in the rise of ethnocratic practices and mobilizations.

In such settings, ethnocratic principles play a critical new role, by creating new hierarchies of civil status between 'veterans' (typically citizens with full rights), and 'newcomers' (often having partial or minimal rights). The normative and legal foundations of this process are rooted in the putative 'ownership' of particular groups over states and public resources. Hence, the institution of citizenship, which was created to overcome feudal or colonial hierarchical systems of privilege and create a universal 'demos', has now - ironically - become a foundation of new, often racist, social hierarchies. 
Urban regimes have become central to shaping these relations as the manifestation of these processes became nearly exclusively urban, with most immigrants congregating in rapidly growing urban regions. This has put in train a process I have conceptualized as 'gray spacing', in which growing groups, areas, developments and economies are being placed, indefinitely, between the 'lightness' of full membership, legality and safety, and the 'darkness' of marginalization, criminality and eviction. This indefinite 'in-betweenness' has structurally marginalized large parts of the population, signalling a new manifestation of ethnocratic norms that rear their head in the current age of capitalist globalization and the associated rapid urbanization (see Yiftachel 2011; Tzfadia 2013).

Gray spacing has become a hallmark of the new metropolis, and hence the foundation of a new political order. One of the main challenges is thus to explore in new research the interaction of ethnocratic and racist, or alternatively liberal or democratic practices, on the emerging or new urban regimes. Given the centrality of cities, the urban order will increasingly become a main battleground for the making of new citizenship and social relations. Although states obviously remain key players, the city is where new colonial relations are being forged, where new mobilizations, democratization and/or marginalization are being established.

'Creeping Apartheid' is therefore emerging as a leading urban political order. The congregation of marginalized, 'partial' citizens in major urban centres has meant that many urban regimes are now - knowingly or unwittingly - facilitating this process through a range of structurally discriminating practices and regulations, in policy areas such as housing, land, development and representation. Apartheid is 'creeping' because these practices and policies remain undeclared, being justified as ‘temporary' or as a result of a 'natural' market or 'international' order. Here, the concept of 'metrozenship' was suggested to offer a new normative and political horizon to de-colonize the emerging exploitive and often racist urban order (Yiftachel 2015). Nevertheless, these urban apartheids too should be considered as 'branches' of the ethnocratic state, as it attempts to control the tensions between persisting governance structures, ethnic and cultural demands, within the latest stage of global capitalism. These regimes must be further studied theoretically and comparatively to better understand their impact on social relations and political transformations. 
Finally, the connection of ethnocracy to Israel/Palestine can, and should, be explored more deeply in line with the suggestions above, and beyond. Further bold, critical, theorizations of such studies will demonstrate that Israel/Palestine is not an exception, as is often argued. It is rather an intense hyper-example of processes commonly evident elsewhere, many of which as 'off-springs' of the ethnocratic order which should be further studied, critiqued and resisted.

\section{References}

Alvarez, M., Cheibub, J., Limongi, F., Przeworski, A. 1996, ‘Classifying Political Regimes’, Studies in Comparative International Development, vol.31, no.2, pp. 3-36. doi: https://doi.org/10.1007/BF02719326

Anderson, J. 2013, 'Imperial Ethnocracy and Demography: Foundations of Ethno-National Conflict in Belfast and Jerusalem', in Pullan, W. and Baillie, B. (eds.) Locating Urban Conflicts; Ethnicity, Nationalism and the Everyday, Palgrave Macmillan, London, pp. 195-213. doi: https://doi.org/10.1057/9781137316882_11 and https://doi.org/10.1057/9781137316882.0019

Brubaker, R. 1996, 'Nationalizing states in the Old New Europe', Ethnic and Racial Studies, vol.19, no.2, pp. 412-437. doi: https://doi.org/10.1080/01419870.1996.9993918

Fenster, T. 2005, 'The right to the gendered city: Different formations of belonging in everyday life', Journal of Gender Studies, vol. 14, no. 3, pp. 217-231. doi: https://doi.org/10.1080/09589230500264109

Howard, M. 2012, 'The Trap of Ethnocracy', Journal of Democracy, vol. 23, no. 4, pp. 155-169. doi: https://doi.org/10.1353/jod.2012.0068

Jamal, A. 2016, 'Conflict theory, temporality, and transformative temporariness: Lessons from Israel and Palestine’, Constellations, vol. 23, no. 3, pp. 365-377. http://dx.doi.org/10.1111/1467$\underline{8675.12210}$

Mostov, J. 1999, 'Women and the Radical State: Ethnocracy and Body Politics', in Ramet, S. (ed), The Radical Right in Central and Eastern Europe since 1989, Pennsylvania State University, University Park, PA, pp. 49-66.

Murtagh, B. and Keaveney, K. 2006, 'Policy and conflict transformation in the ethnocratic city', Space and Polity, vol. 10, no.2, pp. 197-202. doi: https://doi.org/10.1080/13562570600921683

Nagle, J. 2009, 'The right to Belfast City Centre: From ethnocracy to liberal multiculturalism?' Political Geography, vol. 28, no.2, pp. 132-141. doi: https://doi.org/10.1016/j.polgeo.2009.02.002

O'Dowd, L. and Komarova, M. 2011, 'Contesting territorial fixity? A case study of regeneration in Belfast', Urban Studies, vol. 48 no. 10, 2013-2028. http://dx.doi.org/10.1177/0042098010382678

Porter, L. and Barry, J. 2015, 'Bounded recognition: urban planning and the textual mediation of Indigenous rights in Canada and Australia’, Critical Policy Studies, vol. 9, no. 1, pp. 22 - 40. doi: https://doi.org/10.1080/19460171.2014.912960

Remenyi, P. 2011, 'An emerging border of an emerging state? The case of the IEBL and the Republika Srpska of Bosnia-Herzegovina', Eurolimes, vol. 11, pp. 129-141.

Roy, A. 2009, 'Why India cannot plan its cities: informality, insurgence and the idiom of urbanization', Planning Theory, vol. 8 no. 1, pp. 76-87. doi: https://doi.org/10.1177/1473095208099299 
Smooha, S. 1990, 'Minority status in an ethnic democracy: The status of the Arab minority in Israel', Ethnic and Racial Studies, vol. 13, no.3, pp. 389-413. doi: https://doi.org/10.1080/01419870.1990.9993679

Tuathail, G. O. 2013, 'Embedding Bosnia-Herzegovina in Euro-Atlantic Structures: From Dayton to Brussels', Euroasian Geography and Economics, vol. 46, no. 1, pp. 56-67.

Tzfadia, E. 2013, 'Informality as control: the legal geography of colonization in the West Bank', in Chiodelli F., De Carli B., Falletti M. and Scavuzzo L. (eds.), Cities to Be Tamed? Spatial Investigations across the Urban South, Cambridge Scholars Publishing, Newcastle upon Tyne, pp.192-214.

Winant, H. 2001, The World Is a Ghetto: Race and Democracy Since World War II, Basic Books, New York.

Yiftachel, O. 1992, 'The concept of ethnic democracy and its applicability to the case of Israel', Ethnic and Racial Studies, vol. 15, no.1, pp. 125-136. doi: https://doi.org/10.1080/01419870.1992.9993736

Yiftachel, O. 1997, 'Israeli society and Jewish-Palestinian reconciliation: Ethnocracy and its territorial contradictions’, Middle East Journal, vol. 51, no.4, pp. 505-519.

Yiftachel, O. 1999, ‘ “Ethnocracy”: the Politics of Judaizing Israel/Palestine’, Constellations, vol. 6, no. 3, pp. 364-390. doi: https://doi.org/10.1111/1467-8675.00151

Yiftachel, O. 2006, Ethnocracy: Land, and the Politics of Identity Israel/Palestine, University of Pennsylvania Press, Philadelphia.

Yiftachel, O. 2009, 'Theorizing “gray space”: the coming of urban apartheid?', Planning Theory, vol. 8, no.1, pp. 88-100. doi: https://doi.org/10.1177/1473095208099300

Yiftachel, O. 2011, 'Critical theory and gray space: Mobilization of the colonized', in Brenner, N. et al (eds.), Cities for People, not Profit: Critical Theory and the Right to the City, Routledge, London, pp. 94-112.

Yiftachel, O. 2015, 'From gray space to Metrozenship: Reflections on urban citizenship', International Journal of Urban and Regional Research, vol. 39, no. 4, pp. 726-737. doi: https://doi.org/10.1111/1468-2427.12263

Yiftachel, O. 2016, 'Aleph: Jerusalem as critical learning', City, vol. 20, no.3, pp. 483-494. doi: https://doi.org/10.1080/13604813.2016.1166702

Yiftachel, O. and Ghanem, A. 2004, 'Understanding ethnocratic regimes: the politics of seizing contested territories’, Political Geography, vol. 23, no. 4, pp. 647-676. doi: https://doi.org/10.1016/j.polgeo.2004.04.003

Yiftachel, O. and Roded, B. 2010, 'Abraham's urban footsteps: political geography and religious radicalism in Israel/Palestine', in AlSayyad, N. and Massoumi, M. (eds.) The Fundamentalist City? Religiosity and the Remaking of Urban Space, Routledge, London, pp. 178-207.

Yuval-Davis, N. and Werbner, P. 1999, Women, Citizenship and Power, Zed Books, London.

\section{Acknowledgements}

I am grateful to James Goodman and James Anderson for organizing this special issue and for the opportunity to comment. Their initiative is an excellent illustration of the value of global scholarly exchange, without which conceptual, theoretical and political progress would be impossible.

\section{Statement of Conflict of Interest}

The author is unaware of any conflict of interest.

\section{Funding}

No external research funding was used in the development of this Commentary. 